DOI: 10.35757/RPN.2012.20.07

Piotr Madajczyk

\title{
REAKCJE \\ W REPUBLICE FEDERALNEJ NIEMIEC NA POLSKI UDZIAŁ W INTERWENCJI WOJSK UKŁADU WARSZAWSKIEGO W CZECHOSŁOWACJI
}

\footnotetext{
Zamieszczone poniżej dokumenty stanowią swego rodzaju komentarz do publikowanych w tym numerze „Rocznika Polsko-Niemieckiego" opracowań na temat reperkusji wydarzeń 1968 roku w relacjach polsko-(zachodnio)niemieckich. Udział wojsk polskich $\mathrm{w}$ stłumieniu Praskiej Wiosny stanowił obciążenie dla polskiej dyplomacji, aczkolwiek $\mathrm{w}$ mniejszym stopniu niż sugerowałyby to gwałtowne reakcje zachodnioniemieckiej opinii publicznej. Co zrozumiałe więc, polska dyplomacja uważnie obserwowała sytuację w Republice Federalnej Niemiec, nastawienie opinii publicznej, mediów i partii politycznych. Trzy publikowane tutaj dokumenty zawierają informacje przekazywane do centrali w Warszawie. Dwa $\mathrm{z}$ nich przygotowane zostały przez Przedstawicielstwo Handlowe Polskiej Rzeczypospolitej Ludowej w Republice Federalnej Niemiec, mające swoją siedzibę w Kolonii-Marienburg. Trzecie opracowanie, z 18 września 1968 roku, powstało w Berlinie, w strukturach Ministerstwa Spraw Zagranicznych, ale jego autor nie jest znany. Wszystkie trzy dokumenty powstały wkrótce po interwencji wojsk Układu Warszawskiego w Czechosłowacji. Ich autorzy analizują tę sama, wzmiankowaną już, problematykę: sytuacja w RFN po interwencji wojsk Układu Warszawskiego i - co najważniejsze -
} 
jej skutki dla polskiej polityki zagranicznej, zachodnioniemieckiej polityki wschodniej i relacji Polska-RFN.

W publikowanych dokumentach zachowano oryginalną pisownię, poprawione zostały jedynie oczywiste literówki lub pominięcia liter. Pozostawione zostały błędy ortograficzne i gramatyczne oraz sformułowania wprawdzie błędne, ale wynikające z kompetencji językowych, połączonych być może z pośpiechem, autorów opracowań (szczególnie dotyczy to tekstu z 14 września). Nie zostały zaznaczone drobne poprawki, jak nieczytelne wykreślenia słów, kursywą wyróżnione zostały natomiast słowa dopisane ręcznie oraz zachowano podkreślenia oryginału.

1. Informacja Przedstawicielstwa Handlowego PRL w RFN, Köln-Marienburg 14 września $1968^{1}$

AMSZ, DIV 23/75, w. 8.

W dniu 2 września spotkałem się w Kolonii z sekretarzem prasowym intendenta WDR - Dr. Helmut Drück². Rozmówca mój należy do lewicującego odłamu SPD, jest aktywnym członkiem kolońskiego Klubu Republikańskiego.

1. Z jego wypowiedzi wynikało, że wkroczenie wojsk Układu Warszawskiego do Czechosłowacji, które potępił jako akt przemocy, postawiło siły - jak sie wyraził - postepowe i lewicujace wobec poważnego dylematu i zarazem w obliczu głebokiej rozterki. Jak stwierdził mój rozmówca, przygniatająca większość opozycji pozaparlamentarnej, w tym ludzie spod znaku SDS i SHB ${ }^{3}$, związkowcy, uczestnicy marszów wielkanocnych, przeciwnicy służby wojskowej, ustawodawstwa wyjątkowego oraz kampania na rzecz demokracji i rozbrojenia - wszyscy staneli w jednym froncie protestu wraz z dotychczasowymi zdeklarowanymi wrogami ZSRR, mimo indywidualnych prób odcinania się od swych - jak wyraził się - wrogów klasowych. /Na marginesie tej wypowiedzi zaznaczam, że Klub Republikański w Ko-

1 Sygnatura DIV-Og-2417-3-68. Pismo przewodnie podpisał J. Kuczkowski. Do wiadomości utrzymał je wicedyrektor departamentu IV MSZ Tadeusz Hanuszek. Na piśmie adnotacje. „T. Dyr. Czyrek”; „Tow. Czyrek czytał”; "Czarnecki”; „A/a” podpis nieczytelny. Podkreślenia w tekście odręczne.

2 Helmut Drück, po początkowej karierze jako prawnik, pracował od 1965 roku w WDR (Westdeutscher Rundfunk).

3 Sozialistischer Deutscher Studentenbund (Socjalistyczny Niemiecki Związek Studentów) oraz Sozialdemokratischer Hochschulbund (Socjaldemokratyczny Związek Szkół Wyższych). 
lonii rzucił hasło do zorganizowania demonstracji przed budynkiem Radzieckiego Przedstawicielstwa Handlowego/. Drück dodał jednocześnie, że istnieja wprawdzie różnice wśród tego poważnego odłamu posteppowo myślących ludzi co do oceny przyczyn, które skłoniły Układ Warszawski do podjecia tego ostatecznego kroku / nie liczac - jak dodał - znikomego odsetka ortodoksyjnych marksistów którzy maja nieśmiało usprawiedliwiać ów krok - ale w swym rozumowaniu mają być ponoć izolowani/ niemniej jednak końcowy efekt rozumowania, oparty zwłaszcza na przesłankach emocjonalnych /nawet jeśli sa tacy, którzy dopatruja się przejawów kontrrewolucji w CSRS/ prowadzi do kwestionowania prawa ZSRR do thumienia siła nowych rodzacych sie tendencji demokratycznych $\mathrm{w}$ socjalizmie. /Na marginesie tej wypowiedzi dodaję stwierdzenie Hans Joachim Orth, który w krótkiej rozmowie przeprowadzonej ze mna, podkreślił że ludzie, którzy w pełni zdają sobie sprawę z przyczyn, skłaniających Układ Wárszawski do podjęcia wspólnej akcji, znajduja się obecnie w bardzo trudnym położeniu w toku prowadzonych rozmów i dyskusji/.

2. Drück wskazał dalej na swoista psychoze wśród ludności NRF /w dyskusji ze mną zgodził się częściowo, że psychoza ta jest sztucznie wywoływana przez miejscowe czynniki oficjalne oraz zmasowaną propagandę/, która z bojaźnią patrzy w przyszłość. Przytoczył w tym miejscu oklepany już argument, a mianowicie, że jeśli Związek Radziecki nie dotrzymuje zobowiązań wobec swych własnych partnerów, to jakie mamy gwarancje, że i my nie staniemy się ofiarami napaści, zwłaszcza, że wisi nad nami niebezpieczeństwo artykułów o państwach nieprzyjacielskich, mogących zalegalizować taką napaść/.

Kontynuując swą myśl, Drück podkreślił, że owa psychoza /powoływał się przytym na liczne opinie, które mają wynikać z różnych tekstów radiowych/ jest aktualnie woda na młyn wyborczy tych wszystkich, którzy zneutralizowali już zupełnie SPD, przypieczetowujac tym samym jej kleske i z ufnościa patrza w niedaleka przyszłość t.j. na rok 1969, jest woda na młyn rzeczników zbrojeń, wszystkich szermierzy antykomunizmu. Rozmówca mój nie wykluczył, że osoba Kiesingera posłuży, być może, jako lokomotywa wyborcza, z tym, że będzie on najprawdopodobniej wymieniony przez kogoś innego, nawet... [Franza Josefa] Straussa. [Gerharda] Schrödera wykluczył raczej, twierdząc, że jest to człowiek chory oraz, że „Nie byłoby ani taktyczne, ani zreeczne, aby minister obrony przesiadł sie odrazu na stolec kanclerski”. Dodał jednocześnie, że nie można równać pozycji Straussa, mającego za sobą całą Bawarię, z pozycją Schrödera.

Dodatkowym czynnikiem, który miał wpłynąć na szerzącą się psychozę strachu wśród ludności było samo błyskawiczne przeprowadzenie akcji wojskowej w Czechosłowacji, akcji, która była w pewnym sensie zimnym prysznicem dla oficjalnego Bonn. Drück dodał tu, że informacje o zamierzonych planach państw Układu Warszawskiego były ponoć już wcześniej w posiadaniu Urzędu Gehlena, ale miały utknać gdzieś po drodze między Monachium a Bonn. Przytoczył przytym wersję, że „wsiąkły” one w odpowiednie komórki amerykańskie.

3. W dalszym ciagu rozmowy na temat stosunku NRF do wydarzeń w Czechosłowacji nawiązałem do sprawy szerzących się pogłosek na temat włączenia 
się do akcji 701 batalionu Bundeswehry „do spraw prowadzenia wojny psychologicznej”, stacjonującego w pobliżu Andernach nad Renem. /Do batalionu tego, jak wiadomo, należą trzy tzw. LF-Kompanien /Lautsprecher und Flugblatt/ oraz rozgłośnia propagandowa, mogąca nadawać na falach średnich i trzech pasmach fal krótkich. Wiadomo również, że owa rozgłośnia nie ma normalnie zarezerwowanych dla siebie żadnych stałych pasm fal, a co za tym idzie istnieje poważne podejrzenie, że po zamilknięciu kilku rozgłośni czechosłowackich, batalion 701 skorzystał z okazji przeprowadzenia swoistych „manewrów”, podszywając się pod radiostację Pilzno, Budziejowice, „Wolne Radio Czechosłowackie”, „Wolne Radio Północnych Moraw” oraz „Radiostację Nr. 7”. Dodać tu muszę, że owe radiostacje czechosłowackie były świetnie słyszalne w Kolonii, o czym sam mogłem się przekonać, tymczasem ich odbiór w Austrii był ponoć bardzo utrudniony/. Rozmówca mój nie chciał ustosunkować się do tej sprawy, twierdząc, że wybiega to poza kompetencje WDR, niemniej jednak nie złożył żadnego kategorycznego dementi. Wyczułem przytem, że chciał zmienić temat.

Zapytałem go wówczas, jak wyobraża sobie fakt, że siły czechosłowackiej kontrrewolucji tak odrazu, bez przygotowania, zaraz po wkroczeniu wojsk Układu Warszawskiego, mogły uruchomić sprawnie działający aparat antysocjalistycznej propagandy. Czy nie świadczy to o tym, że jeśli nawet nie Bundeswehra, to przynajmniej ludzie wrodzy socjalizmowi liczyli się z tym, że prędzej czy później działalność ich nie może ujść bezkarnie, a co za tym idzie gotowali się do dalszej walki? Drück odparł jedynie, że również dziwi go owa sprawność podziemnych radiostacji czechosłowackich, ale nie zajął w tym względzie żadnego stanowiska, poza wylansowaniem supozycji, że być może owe stacje nadawcze utworzone zostały już za czasów [Antonina] Novotnego przez podziemną partię komunistyczna. /ten sam argument, jak wiadomo, podchwycił później „Quick”.

4. Odnośnie polityki wschodniej NRF wyraził opinię, że jest obecnie mocno przyhamowana, co ma nie oznaczać jednak - jego zdaniem - że po wyklarowaniu się położenia w CSRS będzie podjęta na nowo. Dodał równocześnie, że na tyle na ile jest mu wiadome, podtrzymywana jest nadal w bońskich kołach oficjalnych idea podjecia kontaktów z NRD. Jeśli chodzi o NRD - powiedział dosłownie przełączono jedynie światło z zielonego na żółte a nie na czerwone. Nachodzi jedynie pytanie dodał, czy podjęcie rozmów nastapi na dotychczas proponowanych, szczeblach. Jeśli chodzi bowiem o tę sprawę istnieje duży nacisk ze strony CDU, aby - jak twierdzi się - znaleźć inne formy kontaktów.

\section{X X}

Na marginesie tej ostatniej wypowiedzi Drücka podaję, że zachodnio-niemieckie koła gospodarczo-przemysłowe /a wynika to z różnych kontaktów utrzymywanych przez naszą placówkę/ są raczej zainteresowane w poważnym rozładowaniu napieccia, jakie powstało po wydarzeniach w Czechosłowacji. Potwierdzeniem tego stanu rzeczy może być też powściagliwe wystapienie w Kolonii min. Schil- 
lera $^{4}$, który wypowiedział się przeciwko osłabianiu kontaktów handlowych ze Wschodem.

X X X

W dniu 3 września dokonałem wymiany poglądów z I Sekretarzem. Ambasady ZSRR tow. [Jurijem Anatoljewiczem] Barmiczewem. Rozmówca mój, który wział udział $\mathrm{w}$ spotkaniu [Siemion] Carapkin-Kiesinger, poinformował mnie, że kanclerz federalny był nastrojony pojednawczo i starał się łagodzić za wszelką cenę to wszystko, co mogłoby pogłębić jakiekolwiek podejrzenia odnośnie postępowania NRF zarówno w sprawie Czechosłowacji jak i w sprawie pokoju ogólno-europejskiego. Niemniej jednak wypowiedzi jego odnośnie dobrych intencji w kwestii pojednania $z$ Europa wschodnia nie wybiegły poza ramy oficjalnej postawy bońskiej, a co za tym idzie nie wniosły żadnych nowych elementów ${ }^{5}$.

\section{X X}

W dniu 4 września dokonałem wymiany poglądów z Radcą Ambasady Francuskiej Serge Boixdevaix.

Rozmowa siłą faktu rozpoczęła się od sprawy czechosłowackiej. Uważam przytym na rzecz charakterystyczna, że mój rozmówca francuski przyjał zaprezentowana przeze mnie argumentacje ze zrozumieniem i nie dokonał nawet próby wszczęcia jakiejkolwiek polemiki, z czym liczyłem się poważnie. Odczułem nawet, że w pewnych momentach zajmował pozycję defensywna, zapewniając mnie np. że w intencjach Francji nie leżało nigdy dokonanie wyrwy w obozie socjalistycznym i tym samym załamanie równowagi sił w Europie. Na moje pytanie, czy, zdaniem jego, rząd federalny nie nosił się właśnie $z$ takimi zamiarami w ramach uprawianej t.zw. polityki wschodniej, o czym może chociażby świadczyć aktualny wielki „kociokwik” w stolicy bońskiej, B. wykręcił się odpowiedzią, że chwilowo nie dysponuje dostatecznymi, sprawdzonymi dowodami, które pozwoliły by mu zająć w tym względzie bardziej sprecyzowane stanowisko.

Dalszy ciag rozmowy poprowadziłem w tym kierunku, aby uzyskać od niego jakieś bliższe naświetlenie spotkania [Willy] Brandt-[Michel]Debré $/ 7$ września/ i z kolei zapowiedzianej wizyty [Charles'a] de Gaulla [Gaulle'a] w Bonn.

Rozmówca mój rozwadniał swe wypowiedzi w ogólnikach, twierdząc przykładowo, że spotkanie obu ministrów spraw zagranicznych nie tyle ma związek z przygotowaniem przyjazdu de Gaulla do Bonn, jak sugerowały to niektóre dzienniki, ile raczej leży w ramach rutynowych konsultacji między Francja a NRF. Nie podał jednakże żadnych konkretów. Co się tyczy de Gaulla zapewniał mnie jedynie, że kontynuowanie polityki odprezżenia pozostaje nadal naczelną dewiza pre-

${ }^{4}$ Karl Schiller, polityk CDU, minister gospodarki i technologii w rządzie Kurta Georga Kiesingera.

${ }_{5}$ Na marginesie adnotacja: Rażąco mało z tej rozmowy. 
zydenta Republiki, a co za tym idzie nie może ulegać kwestii, że szef rządu francuskiego będzie starał sie w tym sensie oddziaływać na rzad federalny. Na moje pytanie, czy w aktualnej konfiguracji politycznej, po wypadkach w Czechosłowacji, jest $\mathrm{w}$ stanie w jakiś bardziej konkretny sposób sprecyzować formy polityki odprężeniowej, jaką zamierza inicjować jego rząd, rozmówca mój odpowiedział, że dotychczasowe formy polityki Paryża $w$ tym wzgledzie beda najprawdopodobniej uznane jako nadal aktualne. W tym kontekście dorzucił, iż są w błędzie ci wszyscy w NRF, którzy uważają że możliwości oddziaływania Francji na zewnątrz, po rzekomym nadwątleniu jej prestiżu i siły po wypadkach majowych, osłabły. NRF nadal potrzebuje Francji i to bardziej niż niektórym się wydaje - dodał w konkluzji.

$\mathrm{Z}$ dalszego ciagu wypowiedzi B. wynikało jasno, że akceptuje on wysiłki - jak się wyraził odprężenione kół socjal-demokratycznych z Brandtem na czele, ich pozytywne wychodzenie na przeciw postulatom wysuwanym ze strony Europy wschodniej. Wyraził przytym pogląd, że może tylko niepokojem napawać fakt, że pozycja socjal-demokratów słabnie i spychani sa oni na boczne tory przez siły prawicy lub też zmuszani do włączania się w rydwan ich polityki. Genewskie wystąpienie Brandta, a zwłaszcza niektóre jego fragmenty określił jako rozpaczliwą próbę ze strony SPD ratowania niektórym swych i tak straconych pozycji. Passus wysta-pienia genewskiego federalnego ministra spraw zagranicznych /cytuję za prasą niemiecka/: - „Wir haben nicht nur Verständnis für den Wunsch aller Völker, in gesicherten Grenzen zu leben, sondern wir sind bereit, dem Rechnung zu tragen in Worten und in Taten - ohne Verträgen, wo sie entbehrlich sind, mit Verträgen, wo die der Sache dienen kann" - scharakteryzował jako próbę podania w nowej interpretacji, być może nieco rozszerzonej stanowiska zajętego na Zjeździe w Norymberdze.

Z kolejnych wypowiedzi Boixdevaix należy odnotować jeszcze dwa punkty:

a/ polityka Francji w odniesieniu do dopuszczenia W. Brytanii do Wspólnego Rynku pozostaje bez zmian.

b/ wspólna akcja niemiecko-włoska w kierunku wywarcia nacisku ma Francje w sensie skłonienia jej do zrewidowania swego stosunku wobec NATO nie ma najmniejszego powodzenia.

X X X

W dniu 5 września odbyłem rozmowę z szefem redakcji politycznej kolońskiej TV - Franz Wördemann ${ }^{6}$.

A oto istotniejsze wypowiedzi:

a/ Nastroje wśród ludności niemieckiej, zwiąane z wypadkami w Czechosłowacji przejawiaja sie $w$ bardzo niechętnym stosunku do ZSRR jako całości oraz do kierownictwa SED [Socjalistycznej Partii Jedności Niemiec]. Polska, Wegry i Bułgaria nie sa prawie w ogóle brane pod uwage /tę uwagę Wördemanna potwier-

${ }^{6}$ Niemiecki dziennikarz i publicysta. Pracował w BBC, a od 1957 roku w WDR i kolońskiej Deutsche Welle. Od 1962 roku był redaktorem naczelnym WDR. 
dzają zarówno moje inne kontakty osobiste, jak również kontakty kolegów. Odnosi się wręcz wrażenie, jakby z całą premedytacją starano się wyłączać zwłaszcza Polskę z prowadzonej przeciwko naszemu obozowi wrogiej nagonki propagandowej, co może zakrawać na swoistą próbę dalszego wbijania klina między nasze państwa/.

b/ NRF jest nadal skłonna do szukania punktów stycznych z Polską /udział Polski we wspólnej akcji państw Układu Warszawskiego nie ma na to rzucać większego cienia/ zdaje ona bowiem sobie sprawę, że znalezienie modus vivendi z Warszawą należy do najistotniejszych problemów jej polityki. wschodniej.

c/ rząd federalny jest nadal gotów dawać dowody dobrej woli i z dalszą energią kontynuować swa polityke wschodnia. Nie należy wykluczyć, że NRF nawet teraz byłaby w stanie wylansować nowe ciekawe inicjatywy pokojowe, ale będzie to zależne od stanowiska Zwiazku Radzieckiego. To stanowisko - zdaniem W. będzie swoistym barometrem, pozwoli NRF zdać sobie sprawę na ile jej inicjatywy mogą paść na podatny grunt. Po wypadkach czechosłowackich - jak podkreślił - tok rozumowania w Bonn idzie w tym kierunku, że trudno dawać wiare jakimkolwiek przyszłym ustaleniom z poszczególnymi krajami bloku wschodniego, jeśli ustalenie te moga być w każdej chwili zakwestionowane przez Moskwę, w chwili gdy uzna ona to za wskazane. Obecnie - dodał W. - kampania oczerniania i demonizowania NRF zatoczyła tak wielkie kreegi, że w ogóle trudno jest znaleźć najmniejsze punkty styczne. Wśród szerokich warstw ludności - powiedział dalej - tych warstw, które rozumieją aktualne realia polityczne, zaczyna się coraz bardziej odczuwać zmęczenie i zniechecenie prowadzona przeciwko NRF kampania negowania jej wszelkich posunięć, a zwłaszcza posunięć Brandta, który obecnie już przyciśniety do mury dopasowuje się nolens volens ze wzgleedów taktycznych do linii CDU, utwardza się $\mathrm{w}$ imię ratowania własnej egzystencji i resztek szans wyborczych SPD. Rozmówca mój dodał, że sytuacja zaszła obecnie tak daleko, zwłaszcza po Czechosłowacji, iż w Bonn waża się koncepcje, pod przemożnym naciskiem prawicy, czy jest w ogóle sens szukania jakiegokolwiek porozumienia ze wschodem, czy nie należy narazie odczekać i odwrócić w kierunku zachodnim, przede wszystkim w kierunku $\underline{\text { Stanów Zjednoczonych, które reprezentuja siłe, no i uprawiać polityke wschodnia, }}$ ale na użytek zachodu. Wszystko ma przemawiać bowiem za tym, że cokolwiek będzie nosiło pieczęć „made in West Germany” będzie z reguły odrzucane w dającym się przewidzieć czasie przez państwa Europy wschodniej.

d/ Jednym z przejawów tej polityki wschodniej robionej w obecnej konfiguracji politycznej na użytek zachodu było - zdaniem W. genewskie wystapienie Brandta, w którym wysuwajac możliwość traktatowego uznania granic federalny minister spraw zagranicznych miał na myśli Odrę i Nysę i tym samym poszedł jeszcze dalej niż w Norymberdze.

Na postawione mu w tym kontekście pytanie, czy nie uważa, że bez względu na to, czy polityka wschodnia będzie robiona ,pod Wschód”, czy też „pod Zachód", jej generalny trend będzie sprowadzał się do dalszej retorycznej eskalacji obietnic, ale bez żadnego pokrycia? W. odparł, że osobiście widzi pokrycie dla lansowanych obietnic w realnych szansach uznania granicy na Odrze i Nysie, jak rów- 
nież uznania NRD po wyborach w $1969 \mathrm{r}$. i to nawet jeśli SPD nie wejdzie do rządu, na co zresztą wiele ma - jego zdaniem - dziś wskazywać.

Chcąc w tym miejscu jakgdyby uwiarogodnić swe twierdzenie zaproponował mi zorganizowanie $\mathrm{u}$ siebie $\mathrm{w}$ domu prywatnego spotkania ze swym znajomym podsekretarzem stanu w ministerstwie do spraw przesiedleńców Lemmerem ${ }^{7}$ - dodajac, iż byłoby dla mnie ciekawe wysłuchanie opinii właśnie tego człowieka odnośnie polskiej granicy zachodniej ${ }^{\stackrel{8}{*}}$. Zdaniem W. - Lemmer ma należeć do grupy tych ludzi, dla których nasza granica zachodnia stanowi problem już załatwiony. Na propozycję tę odpowiedziałem, że status mój oraz funkcja w Przedstawicielstwie nie dają mi żadnego asumptu do nawiązywania tego typu kontaktów. Dodałem jednocześnie, że nawet, gdyby przyjęcie tego typu zaproszenia dałoby się zakwalifikować jako mieszczące się w ramach mojego statusu to i tak sam nie mógłbym jego przyjąć $\mathrm{z}$ tego względu, że wybiega ono poza ramy mojej działalności public relations.

W. odparł, że rozumie całkowicie moje zastrzeżenia, niemniej, gdybym doszedł do wniosku, że mógłbym skorzystać z jego prywatnego zaproszenia, jest w każdej chwili do dyspozycji. Dodał jednocześnie, że gdybym chciał skorzystać z jego pomocy w nawiązaniu jeszcze innych interesujących mnie znajomości na gruncie prywatnym /wymienił nawet nazwisko [Franza Josefa] Straussa/ służy zawsze swoją osobą.

e/ Tematu tego nic podtrzymałem i zwekslowałem rozmowę na temat NRD oraz zastopowanych kontaktów [Karl ] Schiller ${ }^{9}-$ [Horst] Sölle ${ }^{10}$ oraz [Werner] Dollinger $^{11}-\left[\right.$ Rudolph] Schulze ${ }^{12}$. W nie potrafił sprecyzować $\mathrm{w}$ jakiej formie zostaną podjęte te kontakty, niemniej wyraził przekonanie, że dojdzie do nich jeszcze w roku bieżącym.

f/ w nawiązaniu do stosunków NRF-Francja W. podkreślił, iż nie należy wykluczyć, że Paryż przedłoży Bonn jakieś sugestie odnośnie wznowienia polityki odprężeniowej, która konkretnie w NRF stoi na rozdrożu w wyniku znacznego zradykalizowania się sił prawicy pod wpływem wypadków w Czechosłowacji. W kontekście tym dodał, iż zaczyna znów brać góre orientacja proamerykań$\underline{\text { ska }}^{13}$. Rzecznicy tej orientacji, rekrutujący się z kół chrześcijańskiej demokracji

7 Prawdopodobnie w tekście użyte zostało niejasne sformułowanie, gdyż zapewne chodzi o Ernsta Lemmera, polityka CDU, w latach 1964-1965 ministra do spraw wypędzonych, uchodźców i ofiar wojny. W latach 1966-1968 Lemmer był specjalnym pełnomocnikiem kanclerza do spraw Berlina.

8 Na akapicie adnotacja odręczna: Poszła depesza, że niewskazane.

9 Minister gospodarki RFN. Wspomniane rozmowy rozpoczęły się na początku sierpnia na jego zaproszenie, a przerwane zostały przez wydarzenia w Czechosłowacji.

${ }^{10}$ Minister handlu NRD.

${ }^{11}$ Minister poczt i telegrafów RFN. Prowadzone rozmowy dotyczyły uregulowania zasad ruchu pocztowego między dwoma niemieckimi państwami.

${ }^{12}$ Minister poczt i telegrafów NRD.

${ }^{13}$ Na marginesie odręczna adnotacja: A kiedy nie była górą? 
stoją na stanowisku, iż Francja jako taka nie stanowi żadnego bastionu, ani gospodarczego ani militarnego, na który mogłaby liczyć NRF w sytuacji bezpośredniego zagrożenia ze Wschodu. Odnośnie spotkania Brandt-Debré, W. w przeciwieństwie do tego, co powiedział mi radca Ambasady Francuskiej, oświadczył, że federalny minister spraw zagranicznych udaje się do Paryża na specjalne życzenie strony francuskiej, a więc nie chodzi tu tylko o normalne rutynowe konsultacje. Życzenie to miało być raz jeszcze ponowione mimo podjęcia określonych ustaleń w tym względzie jeszcze w Brukseli.

X X X

W dniu 10 września przeprowadziłem rozmowę z Alard von Schack, publicysta, współorganizatorem dyskusji politycznych w Akademii Ewangelickiej Loccum, mającym powiązania z bońskim MSZ oraz Deutsche Gesellschaft für Auswärtige Politik.

W dniu 11 września natomiast bawił u mnie w mieszkaniu na kolacji boński korespondent „Combat” i „La Vie Française” - Jean Roussel z żoną. W tejże kolacji wziął także udział I sekretarz Ambasady ZSRR J. A. Barmiczew oraz sekretarz naszej P[odstawowej]O[organizacji]P[partyjnej] Andrzej Włodyka z żoną.

Najistotniejsze wypowiedzi, jakie padły podczas obu tych spotkań można sprowadzić do następujących punktów /oczywiście chodzi tu o wypowiedzi von Schack i Roussel/:

1. Wkroczenie wojsk Układu Warszawskiego do Czechosłowacji, a zwłaszcza wojsk ZSRR /i te tylko praktycznie są brane w rachubę/ stwarza według miejscowych ocen istotne zagrożenie dla NRF, gdyż następuje zmiana układu sił w Europie z punktu widzenia strategicznego, zmiana w sensie negatywnym.

2. W związku z tym stanem rzeczy /było to zakomunikowane mi w formie pogłosek/ miano rozważać możliwości takiej dyslokacji sił Bundeswehry, która odpowiadała by zachwianej równowadze sił. Łączyło się to z ogólnym podniesieniem gotowości bojowej Bundeswehry. W kołach CDU rozważano nawet możliwość skierowania silnych oddziałów wojskowych na granice czeska zaraz po wkroczeniu do Czechosłowacji wojsk Układu Warszawskiego po to aby uspokoić przerażona opinię publiczna /należy tu dodać na marginesie, że nastroje poważnego niepokoju sa po dziś dzień żywe wśród szerokich warstw społeczeństwa zachodnio-niemieckiego, nastroje, które sie sztucznie podsyca gwoli dyskontowania ich na niwie politycznej/.

$\mathrm{W}$ kołach bońskich mówi sie ponadto o wydatnym wzmocnieniu oddziałów_Grenz[s]chutzu /wyposażenie go m.in. w sprzęt przeciwczołgowy/ oddziałów policji /uzbrojenie jej np. w ciężka broń/, jak również o istniejacych tendencjach zwiększenia kompetencji Bundu w odniesieniu do policji poszczególnych Landów. Do tego dochodzi przezbrajanie zachodnio-niemieckiej Luftwaffe, jak sie to określa w najnowocześniejszy sprzęt przystosowany do prowadzenia wojny w warunkach konwencjonalnych, podejmuje się kroki, które maja ulepszyć przeprowadzenie mobilizacji na wypadek konfliktu. 
Jeśli chodzi o działalność na niwie politycznej, Bonn liczy się jeszcze ciagle, że w październiku uda się zwołać konferencję państw NATO, że uda mu się wygrać propagandowo posiedzenie grupy planowania nuklearnego NATO, które ma odbyć się w połowie października w stolicy NRF /mimo, iż posiedzenie to jest nazywane czysto rutynowym, chodzi właśnie o wygranie tego faktu $w$ obecnej konstelacji politycznej, że odbędzie się ono w Republice Federalnej, w kraju, który znajduje się na pierwszej linii frontowej/. W stolicy bońskiej rozważa się ponadto możliwość reaktywowania Europejskiej Wspólnoty Obronnej /Europa sama musi sobie pomóc/, która składałaby się z połączonych sił atomowych Francji i W. Brytanii oraz wydzielonych oddziałów Bundeswehry /kursują pogłoski, dementowane zresztą przez Auswärtiges Amt, jakoby w reaktywowaniu Europejskiej Wspólnoty Obronnej mieli przejawić jakieś inicjatywy Francuzi/. Wysyła się ponadto Kurt Birrenbacha do USA, mającego znakomite powiązania z amerykańskim gospodarczym i politycznym High Society./ sam Birrenbach jak wiadomo, jest przewodniczącym rady zawiadowczej Spółki z.o.o. Thyssena w Düsseldorfie, przewodniczącym rady nadzorczej August-Thyssen-Hütte-AG/Duisburg-Hamborn, członkiem licznych rad nadzorczych Montan-Industrie, członkiem centralnego beiratu Dresdener Bank/, jak również Helmuta Schmidta.

$\mathrm{Z}$ przeprowadzonych przeze mnie rozmów wynikało, że Birrenbach miał przedłożyć swym rozmówcom amerykańskim punkt widzenia kanclerza federalnego i CDU na konieczność większego zaangażowania się militarnego USA w Europie środkowej i zachodniej, na zastopowanie dalszego wycofywania wojsk amerykańskich z NRF, na istotna role, jaka moga odegrać Stany Zjednoczone w przeciwstawianiu sie - jak to określono - kampanii oszczerstw i obelg prowadzonej przez ZSRR przeciwko NRF /ta sprawa miała być już ponoć poruszana przez [Swidberta] Schnippenköttera ${ }^{14} \mathrm{w}$ Genewie/, jak również na niewywieranie nacisku na NRF w sprawie podpisania układu o nierozpowszechnianiu broni jądrowej /tę pewność miały już koła bońskie przed wyjazdem Birrenbacha do USA/.

Zadanie Schmidta ma być podobne i polegać na wybadaniu, na co Republika Federalna może liczyć w Stanach Zjednoczonych.

W kontekście obu tych wizyt lansowane sa w Bonn spekulacje, że po wyborze [Richarda] Nixona na prezydenta USA, Stany Zjednoczone zaangażują sie silniej

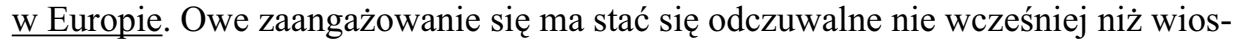
ną przyszłego roku.

3. Jeśli chodzi o polityke wschodnia, w tym również w odniesieniu do Polski, musi ona, według przeważajacych opinii oficjalnych, w praktyce zostać zamrożona. Jej ewentualne posunięcia mają być warunkowane dalszą postawą ZSRR. Schack wychodzi z założenia, iż przynajmniej w dającym przewidzieć się czasie, wszystko wskazuje na to, że najmniejsza choćby inicjatywa NRF będzie odrazu storpedowana.

W tym kontekście powiedział on, że według zgodnej oceny miejscowych kół, akcja wojskowa ZSRR była w rzeczywistości błyskotliwym, ale tylko doraźnym sukcesem. Ma się odnosić bowiem wrażenie, że polityczne skutki tego kroku nie były

\footnotetext{
${ }^{14}$ Niemiecki dyplomata, od 1969 roku stały przedstawiciel w ONZ. W roku 1968 znajdował się w Genewie, gdyż uczestniczył w rokowaniach rozbrojeniowych.
} 
wzięte pod uwage $\mathrm{i}$ to był największy błąd. $\mathrm{Z}$ podtekstu dalszych wywodów odniosłem wrażenie, iż według miejscowych ocen, Bonn chce przede wszystkim odczekać na dalszy rozwój wydarzeń w Europie wschodniej /jest m.in. duże zainteresowanie naszym zjazdem i do naszych dziennikarzy napływaja już zapytanie na temat szans przyjazdu do Polski/ i południowo-wschodniej, licząc, że rozwój ten będzie ewoluował w sensie negatywnych dla naszego obozu, co z kolei pozwoli wyciagnać dalsze wnioski dla zachodnio-niemieckiej polityki. W tym kontekście padła dość charakterystyczna wypowiedź, a mianowicie, że o ile komunizm w wydaniu radzieckim jest zupełnie nie do przyjęcia w NRF i nie ma tu żadnej podatnej gleby, zwłaszcza po wypadkach w Czechosłowacji, o tyle komunizm w nowym wydaniu czechosłowackim ma szanse znalezienia stronników wszędzie. Taki komunizm mógłby być nawet „zagrożeniem” dla NRF i kto wie czy dla Europy nie okazałby sie zbawienny.

Jeśli chodzi o NRD i ewentualne wznowienia kontaktów na linii Bonn-Berlin Wschodni, obaj rozmówcy nie wypowiedzieli się zbyt precyzyjnie, twierdząc jedynie, że do tych kontaktów dojdzie najprawdopodobniej wcześniej lub później, z tym, że pozycja NRF może ulec $\mathrm{w}$ trakcie przyszłych rozmów utwardzeniu ze względu na zdyskredytowanie się kierownictwa SED, zdyskredytowania się zwłaszcza w tym sensie, że podważyło ono wiarogodność swych dążeń do uznania państwowości NRD.

4. Schack zdementował kategorycznie informacje o udziale batalionu radiowego 701 Bundeswehry w akcji dywersyjnej przeciwko Czechosłowacji. Oświadczył przytym, że przeprowadzono już dokładnie badania tej sprawy i okazało się, że batalion radiowy nie opuszczał swego miejsca postoju na Renem. Powiedział także. że t.zw. Arbeitsstab Wenzel, którym ma jakoby kierować dowódca II korpusu Bundeswehry gen. [Karl Wilhelm] Thilo, jest zwykła fikcja. Nazwiska członków „Arbeitsstab Wenzel" - wg. jego wersji miały być wyjęte z archiwów NRD i dotyczyć oficerów, którzy kiedyś parali się sprawami psychologicznego prowadzenia wojny.

5. Odnośnie przyszłych szans rozwoju wewnętrznej sytuacji NRF, obaj rozmówcy byli zgodni co do tego, że CDU/CSU żeglują w kierunku pełnego zwycięstwa wyborczego. Niewiadome jedynie, czy chrześcijańska demokracja będzie chciała rządzić sama, czy też będzie szukała koalicji z FDP. Pozycja Brandta, który dopasowuje się do twardej linii CDU została określona jako godna pożałowania. Kiesinger zachowa fotel kanclerski. Straussa typuje się ponownie na ministra obrony. Na sukcesję po [Heinrichu] Lübke szykują się ze strony SPD [Georg] Leber i [Gustav] Heinemann, ze strony CDU [Eugen] Gerstenmaier i [Gerhard] Schröder. Według aktualnych prognoz większe szanse mają mieć kandydaci CDU, z tym że na czoło ma wysuwać się Schröder.

X X X

W dniu 12 września spotkałem się w Kolonii z kierownikiem bońskiej placówki ČTK ${ }^{15}$ - Otakar Sverčina.

${ }^{15}$ Československá tisková kanceláŕ - Czeska Agencja Prasowa. 
Bieg wydarzeń w swoim kraju począwszy od plenum styczniowego oceniał w sposób realistyczny i i nie szczędził nawet cierpkich uwag pod adresem kierownictwa partii, które jego zdaniem, popełniło sporo błędów. Stwierdził, że Dubczeka i jego ekipę traktował już dawno jako coś przejściowego. Dodał ponadto, że w ostatnim czasie sam był nie mile widzianą osobą w Pradze, ze względu na reprezentowane poglądy. Jednocześnie jednak starał się dowodzić, że rozwój wypadków w jego kraju absolutnie nie usprawiedliwiał - jak sie wyraził - interwencji zbrojnej „,i to w dodatku przy udziale Niemców z NRD”. Jednym z jego argumentów na poparcie tej tezy było rzekomo fałszywe rozeznanie sytuacji przez Związek Radziecki, które doprowadziło do wyciagnnięcia niewłaściwych wniosków dania sygnału „do tej nieprzemyślanej do końca akcji zbrojnej”. Wg. opinii S. nie doceniono też ogólnych konsekwencji politycznych, konsekwencji, jakie pociagnie to dla międzynarodowego ruchu robotniczego i komunistycznego /wygrywanie sprzeczności przez naszych wrogów/, konsekwencji dla przyszłych stosunków czechosłowacko-radzieckich. W tym miejscu dodał, że nigdy w historii jego kraju nie został tak do białości rozpalony nacjonalizm, który przez wiele lat będzie rzutował negatywnie na przyszły rozwój kontaktów CSRS-ZSRR. Zaryzykował też pogląd, że być może dojdzie już niedługo do zmian w kierownictwie radzieckim, zmian, które staną się następstwem fałszywej oceny sytuacji w jego kraju.

W dalszym ciagu rozmowy poinformował mnie o istnieniu w pierwszej fazie wydarzeń dużych nacisków na grupe dziennikarzy czeskich akredytowanych w Bonn, by odmówili powrotu do kraju. Skorzystał z tego dotychczas tylko jeden, a mianowicie przedstawiciel praskiego radia Dr. Vilem Fuchs. Federalny Urząd Prasy zaofiarował też, pomoc materialną dziennikarzom czechosłowackim, z której jednak mieli nie skorzystać.

Jeśli chodzi o Czechosłowackie Przedstawicielstwo Handlowe we Frankfurcie/ Menem, funkcjonuje ono normalnie w dotychczasowym składzie osobowym.

Co się tyczy grupy dziennikarzy czechosłowackich, która przybyła $\mathrm{z}$ wizyta do NRF w pierwszej połowie sierpnia br, trzech jej członków odmówiło powrotu do kraju, a mianowicie obaj przedstawiciele radia oraz red. nacz. "Volkszeitung”. Ten ostatni nawiazał kontakt $\mathrm{z}$ redakcja „Sterna” i wybiera sie jako korespondent tego tygodnika do Belgradu ${ }^{16}$.

W kontekście dalszej rozmowy $\underline{\text { S. nie wykluczył, że podczas debaty politycznej }}$ w Bundestagu przy końcu bm., strona zachodnio-niemiecka wysunie jakaś nowa formułe anulowania Układu Monachijskiego.

Odnośnie lansowania różnych wersji na temat podjęcia działalności przez batalion 701 Bundeswehry - S. wykluczył dywersyjną działalność ze strony NRF i powiedział, że podziemne radiostacje, które rozwijały akcje w Czechosłowacji były radiostacjami armii czeskiej.

\footnotetext{
${ }^{16}$ Na marginesie odręczna adnotacja: ?.
} 
2. Notatka „Reakcja kół oficjalnych i środowisk poza rządowych NRF na stanowisko Polski i obecność oddziałów polskich w Czechosłowacji”, ${\text { Berlin } 18 \text { września } 1968, \text { poufne }^{17}}^{17}$

AMSZ, sygn. DIV 23/75, w. 8

Opracowano po rozmowie z naszymi korespondentami w Bonn i na podstawie naszych kontaktów.

Szersza część opinii w NRF pozbawiona zdolności do samodzielnych ocen pozostaje pod wpływem niezwykle agresywnej propagandy masowych środków przekazu. Najbardziej ujemne chwilowo skutki odnotować należy w tych środowiskach zachodnioniemieckich, które od lat wystepowały z pozytywnymi inicjatywami uregulowania stosunków z Polska i z krytyka polityki rzadu NRF, badź sympatyzowały z polskimi inicjatywami pokojowymi. Czuja sie one zawiedzione i izolowane, co nie oznacza jednak, że argumenty ich np. co do uznania granicy zostały zdyskredytowane. Wykorzystując wydarzenia marcowe i sprawę Czechosłowacji, propagandzie NRF udało się znacznie osłabić nasze oddziaływanie na sprzyjajace Polsce środowiska w NRF, zwłaszcza poprzez przeciwstawienie sytuacji w Polsce t.zw. demokratycznemu socjalizmowi w Czechosłowacji. Zaangażowanie się w obronę „demokratycznego" socjalizmu czeskiego, przy starannym zacieraniu poparcia dla rozwoju kontrrewolucji, w propagandzie NRF stało się też główną przyczyną braku zrozumienia w tutejszej opinii dla motywów uzasadniających akcję pięciu krajów socjalistycznych. Tylko znikoma ilość ludzi w NRF wierzy w rezultacie w zagrożenie socjalizmu w Czechosłowacji. Na pozycjach takich oprócz KPD ${ }^{18}$ staneła praktycznie tylko DFU ${ }^{19}$.

Okazję do bezpośredniego ataku na Polskę, spotęgowanie wrogości przeciwko nam wykorzystały ugrupowania tradycyjnie antypolskie. Środowiska syjonistyczne próbowały ożywić oskarżenie nas o antysemityzm, wykorzystując przykłady naszej krytyki działalności elementów syjonistycznych w Czechosłowacji. Środowiska te z małą skutecznością usiłowały rozpowszechnić tezę, że u podstaw naszego stanowiska w sprawie Czechosłowacji i wkroczenia wojsk leżał antysemityzm.

Potencjalna możliwość sprzyjania niektórych kręgów naszemu stanowisku została podważona postawą partii komunistycznych w zachodniej Europie, szeroko rozpropagowaną i wykorzystaną przez propagandę NRF. Telewizja NRF posłużyła się tu zwłaszcza szeregiem rewizjonistycznych działaczy pochodzenia żydowskiego.

Zasadnicze cele propagandy NRF w związku z wydarzeniami w Czechosłowacji zmierzały do skompromitowania akcji naszych krajów jako aktu okupacji i stwo-

${ }^{17}$ Na piśmie odpisana ręczenie sygnatura DIV-Og-2417-3-68 oraz adnotacja „załącznik do pisma No. 0-24/8/68". Podkreślenia w tekście ołówkiem. Notatka podpisana inicjałami JM/HH, zapewne Przedstawicielstwa Handlowego PRL w RFN.

${ }^{18}$ Kommunistische Partei Deutschlands - KPD, Komunistyczna Partia Niemiec.

${ }^{19}$ Deutsche Friedensunion, założona w 1960 roku partia, która zastąpić miała zdelegalizowaną KPD. 
rzenia atmosfery zagrożenia komunistycznego również dla NRF. Wyraźnie chodziło o zniweczenie zaufania do pokojowego charakteru polityki radzieckiej, w związku z czym NRF różnymi metodami dążyła do sprowokowania szerszego konfliktu, jak zbrojnego starcia w Czechosłowacji i rozlewu krwi, wywołania stanu napięcia poprzez insynuowanie rzekomych zamiarów akcji wojskowej przeciwko Rumunii i Jugosławii oraz przez eksponowanie perspektywy interwencji w NRF w oparciu o klauzule ONZ dot. państw nieprzyjacielskich. Ofensywa ta miała przysłonić zaangażowanie NRF w poparciu rozwoju kontrrewolucyjnego w Czechosłowacji i uchronić rząd boński przed odpowiedzialnościa za prowadzenie awanturniczej polityki. Już obecnie dostrzec można małą skuteczność tej taktyki. Opinii w NRF nie zdołano narzucić wrażenia niebezpieczeństwa ze Wschodu oraz wywołać masowej psychozy antykomunistycznej. Natomiast dość szeroko upowszechniło się przekonanie o zdecydowanej klęsce, jaka poniosła polityka wschodnia rządu NRF. Obserwujemy w związku $\mathrm{z}$ tym istotną zmianę w postawie kół oficjalnych i propagandy NRF, co znajduje wyraz $\mathrm{w}$ dążeniu do wycofywania się $\mathrm{z}$ roli głównego w Europie czynnika zaostrzania sytuacji. Jednocześnie rząd boński rozwija dużą aktywność zakulisową w kierunku ujednolicenia stanowisk państw NATO, skłonienia głównie Stanów Zjednoczonych do bardziej stanowczej postawy w sprawie Czechosłowacji i pozyskanie propagandowo-politycznego zabezpieczenia spodziewanych ujemnych skutków dla NRF. /Misja Birrenbacha i Schmidta w USA ${ }^{20}$./ Niepewność i obawy kół bońskich o skutki polityczne dla NRF znalazły wyraz w wystapieniu H.[erberta] Wehnera bezpośrednio po 21 sierpnia, w którym próbował z góry przygotować opinię na reakcję naszych krajów wobec Bonn oraz w wypowiedziach R.[ainera] Barzela, ujawniających zdenerwowanie Bonn z powodu stanowiska mocarstw zachodnich wobec akcji K[rajów]S[ocjalistycznych] w Czechosłowacji.

Aktualne nastroje w opinii publicznej NRF wobec Polski odzwierciedlaja znaczny stopień postawy antypolskiej. Przeważa niezadowolenie z pokrzyżowania nadziei NRF na osłabienie wspólnoty krajów socjalistycznych i powstrzymanie ekspansji NRF. Znamienne jest jednak nieeksponowanie otwartych ataków na Polskę $\mathrm{w}$ wystapieniach oficjalnych i w masowych środkach przekazu, nie licząc prasy springerowskiej. Przyczyny tego zjawiska mogą być różne. Wynikają prawdopodobnie z generalnej dyrektywy skoncentrowania ataku na Związek Radziecki i na podstawy jedności państw socjalistycznych. Dalsze powody tkwią w zamiarach Bonn pozostawienia nadal otwartych drzwi w polityce wschodniej oraz w ra-

${ }^{20}$ Socjaldemokrata Helmut Schmidt mianowany został przez SPD (Sozialdemokratische Partei Deutschlands, Socjaldemokratyczna Partia Niemiec) specjalnym wysłannikiem do USA 27 sierpnia 1968 roku. Niespełna tydzień później CDU (Christlich-Demokratische Union, Unia Chrześcijańsko-Demokratyczna) mianowała jako swojego specjalnego wysłannika do USA Kurta Birrenbacha, posła CDU, a zarazem stojącego na czele rady nadzorczej firmy Thyssen. Nominacje te były przyczyną konfliktu w ramach rządzącej koalicji, ponieważ ministrem spraw zagranicznych RFN był socjaldemokrata Willy Brandt, a kanclerz Kurt Kiesinger mianował Birrenbacha „specjalnym ambasadorem kanclerza" w USA, wkraczając tym samym w kompetencje Brandta. 
chubach na ewent. rozbieżności w Polsce przed Zjazdem partii i unikanie działania mogacego umocnić obecne kierownictwo polskie. Na uwage zasługuje też umiarkowana postawa Bonn wobec NRD. Wprawdzie NRD jest drugim po ZSRR obiektem ataków, jednakże Bonn nie wycofało propozycji kontaktów ministerialnych z NRD, a nawet postulowano aktualność spotkania ministrów Gospodarki.

Dotarcie naszej argumentacji do opinii w NRF jest znikome. $Z$ materiałami drukowanymi możemy dotrzeć tylko do niewielkiej ilości osób. Masowe środki przekazu NRF oddają stanowisko Polski w sposób fragmentaryczny, tendencyjny, bądź wyselekcjonowany pod kątem potwierdzenia własnych tez. Dotychczasowy kierunek naszej argumentacji jest słuszny i znajduje cześciowe zrozumienie. Skuteczne są zwłaszcza argumenty o próbie zachwiania układu sił. Przemawiają do pewnych środowisk fakty $\mathrm{i}$ komentarze, odsłaniające role Bonn w czynnym poparciu kontrrewolucji. Niepokój i krytykę u rozmówców wywołują przykłady kontaktów bońsko-czeskich sprzed 21 sierpnia i próby nakłaniania do zerwania przez Czechosłowacje jej porozumień traktatowych i zobowiązań w stosunku do KS. Dlatego też w naszej propagandzie należałoby dażyć do jeszcze silniejszego eksponowania niebezpiecznego dla pokoju a zamaskowanego kierunki polityki Bonn i przeciwstawienia temu naszej głębokiej troski o pokój oraz znane zaangażowanie w rozwijaniu inicjatyw pokojowych. Wśród inspiratorów ataków przeciwko Polsce wymienić należy organizacje ziomkowskie, koła syjonistyczne i koncern Springera. Gazety takie, jak „Die Tat”, „Köllner Stadtanzeiger”, „Der Stern” i częściowo prasa FDP uwzględniają w pewnym stopniu naszą argumentację. Wyjątkową agresywność przejawiają rozgłośnie rządowe Deutsche Welle i Deutschlandfunk oraz drugi program telewizji, nie wymierzoną jednak wprost przeciwko Polsce. Podobną postawę zajęły główne ośrodki I TV /ARD/ jak Bayerischer Rundfunk, Westdeutscher Rundfunk, Norddeutscher Rundfunk i S[ender]F[reies]B[erlin]. Szczególnie wojowniczą rolę odgrywa rozgłośnia RIAS w Berlinie zachodnim. Mniejszą agresywność wykazały Hessischer Rundfunk, Südwestfunk i Radio Bremen.

Naszych sojuszników widzimy wśród ludzi, którzy na podstawie dobrej znajomości Polski nie ulegają propagandzie i nie wierzą w naszą agresywność, a przekonani są o naszym internacjonalizmie. Środowisko tych osób przyjmuje obecność naszych wojsk w Czechosłowacji jako konieczność.

W naszym przeciwdziałaniu skoncentrowaliśmy uwagę na dotarciu ze stanowiskiem Polski do osobistości politycznych i przedstawicieli masowych środków przekazu. W trzech szybko wykonanych biuletynach zamieściliśmy najważniejsze oświadczenia oficjalne i komentarze prasowe. Mamy sygnały o zainteresowaniu odbiorców treścią biuletynów. Nie mieliśmy żadnych demonstracyjnych zwrotów. Materiał nasz nie jest jednak wykorzystywany do przedruków w prasie NRF. Możliwość inspiracji dziennikarzy jest przy aktualnym nastawieniu kierownictwa redakcji i rozgłośni znikoma. Nie ma też zainteresowania dziennikarzy dla wyjazdów informacyjnych do Polski.

Nasuwa się wniosek, że w obliczu zmasowanej propagandy NRF nie sposób szerzej i skuteczniej przeciwstawić naszej argumentacji bez ścisłej praktycznej 
współpracy z NRD i poprzez jej środki przekazu obejmujace swym zasięgiem terytorium $\mathrm{NRF}^{21}$.

Wg opinii naszych korespondentów w Bonn licza się z naszym stanowiskiem. Nasza argumentacja ma w rozeznaniu Bonn znaczenie w krajach socjalistycznych i na Zachodzie. Istnieją przesłanki pozytywne do wzmożenia naszego aktywnego oddziaływania. Korespondenci obserwują tendencję w kołach bońskich do poszukiwania dróg wyjścia z impasu, w jakim znalazła sie polityka wschodnia NRF. Sadza, że Bonn nie może pozwolić sobie na bezruch w polityce wschodniej spowodowany nasza akcja w Czechosłowacji. Uważaja, że Bonn może silniej brać pod uwage uznanie naszej granicy i podpisanie układu o nierozprzestrzenianiu jako elementów przetargu za rezygnacje przez ZSRR i klauzuli dot. państw nieprzyjacielskich. Uznanie NRD - stwierdzaja nasi korespondenci - nadal nie leży w sferze rozważań Bonn. Aktualna jest natomiast sprawa kontaktów rzadowych z NRD. Sugeruja $\mathrm{w}$ tej sytuacji wystapienie kogoś $\mathrm{z}$ naszego kierownictwa $\mathrm{z}$ podkreśleniem naszej konstruktywnej i odpowiedzialnej polityki pokojowej, tak aby nie mogło ono być na Zachodzie pominięte, lub przemilczane. Dalszym elementem wystapienia mogłaby być ostra krytyka antypokojowej polityki rzadu NRF oraz wskazanie perspektyw pokojowego współżycia.

Sprzyjajaca sytuacja dla naszych konstruktywnych wystapień istnieje w $\mathrm{FDP}^{22}$. Partia ta ze względów wyborczych i opozycyjnych przyjęła postawę krytyczną wobec stanowiska rządu bońskiego w kwestii wydarzeń w Czechosłowacji. Krytykuje zwłaszcza kierunek na zmiane status quo i opowiada sie za francuska koncepcja polityki wobec krajów socjalistycznych.

3. Notatka Przedstawicielstwa Handlowego PRL w RFN „Aktualna sytuacja w lewicy NRF po wydarzeniach w Czechosłowacji, Köln-Marienburg 8 październik $1968^{23}$

AMSZ, sygn. DIV-Og-2417-3-68

1. Stanowisko, jakie zajęła nowo ukonstytuowana Niemiecka Komunistyczna Partia wobec wydarzeń w Czechosłowacji, jak również jej stosunek do państw obozu socjalistycznego jest jednoznaczny w naszym rozumieniu tego słowa i nie wymaga komentarzy. Wynika to zresztą jasno z oświadczenia DKP ${ }^{24}$ z 22 września br.

${ }^{21}$ Akapit dodatkowo, poza podkreśleniem, zaznaczony ołówkiem.

${ }^{22}$ Freie Demokratische Partei, Wolna Partia Demokratyczna.

${ }^{23}$ Na piśmie odręczne adnotacje: „T. Dyr. Czyrek”; „Tow. Czyrek czytał”; Tow. Kuczma z prośbą o omówienie" nieczytelny podpis; "a/a" nieczytelny podpis. PH PRL przesyłało równocześnie niepublikowaną tu notatkę „NRF-NATO” o syg. DIV-Og-241311-68. Notatka podpisana inicjałami JK/JW.

${ }^{24}$ Deutsche Kommunistische Partei (Niemiecka Partia Komunistyczna), założona w 1968 roku w miejsce zdelegalizowanej KPD. 
2. Stanowisko w tym względzie zajmowane przez opozycję pozaparlamentarną jest nadal wobec nas nawskroś negatywne, choć, co jest godne podkreślenia, mamy już poza sobą etap histerii, etap rozpalania różnych namiętności.

Obrazowo możnaby przedstawić sytuację w tym zlepku najrozmaitszych ideologii w sposób następujący: jądro złożone z najbardziej lewicowych i świadomych dziataczy, liczebnie jednak minimalne, szuka argumentów na usprawiedliwienie naszej akcji podjętej w Czechosłowacji. Owe jądro otoczone jest jednak wieloma nawarstwionymi słojami, które je tłamszą i narzucają bez reszty swój punkt widzenia, który sprowadza się do jednoznacznego potępiania kroków wojskowych państw Układu Warszawskiego /szczególnie nie znajduje absolutnego zrozumienia udział wojsk polskich we wspólnej akcji/ i szukania argumentów, zmierzających jedynie do torpedowania naszych pozycji. Ten nacisk jest tak silny, że owe jądro naszych potencjalnych sojuszników nie ośmiela się nawet ujawniać zbyt głośno swych poglądów, aby nie zostać, jak to określa się, wyrzucone za burtę. Oczywiście wszystko to nie przeszkadza, że opozycja pozaparlamentarna pozostaje nadal przy swych podstawowych hasłach, występujących przeciwko wojnie w Wietnamie, atakujących koncepcje polityczne USA, wypowiadających się na rzecz rozbrojenia, osłabienia spoistości Bundeswehry itp. Warto przytem podkreślić, że wydarzenia w Czechosłowacji zbiegły się z dużymi wstrząsami ideologicznymi i organizacyjnymi, jakie przeżywała opozycja pozaparlamentarna po represjach zastosowanych wobec niej w wyniku inicjowania wielkich akcji przeciwko Springerowi i ustawodawstwu wyjątkowemu. Był to okres kiedy oficjalne Bonn w oparciu o chrześcijańskie ugrupowania studenckie/jak wiadomo zaś opozycja pozaparlamentarna ma swe najsilniejsze bazy na wyższych uczelniach/ zaczęło organizować kontrdemonstracje, zainicjowało szeroką akcję odczytową i propagandową, nie mówiąc już o licznych akcjach tego typu jak rewizje i aresztowania. Reasumując można stwierdzić, że przynajmniej aktualnie nie możemy jeszcze liczyć w żadnym wypadku na jakiekolwiek poparcie ze strony opozycji pozaparlamentarnej jako takiej dla naszego stanowiska lub też zmianę jej nastawienia do 5 państw naszego obozu. 3. Lewica SPD przynajmniej obecnie przycichła zupełnie i nie ujawnia się, zwłaszcza kiedy kierownictwo tej partii zarzuciło swe podstawowe tezy polityczne i pod presją opinii na wydarzenia w Czechosłowacji /należy w to też wkalkulować poważny aspekt wyborczy/ zaakceptowała pozycję CDU w sprawie tzw. polityki odprężeniowej, którą uznano za nieaktualną oraz w sprawie niepodpisywania układu o nieproliferacji /choć z oporami - gwoli ścisłości/.

W tej grupie ludzi nie tylko nie mamy sojuszników, lecz raczej ludzi, którzy ostro atakują nasze stanowisko w kwestii Czechosłowackiej.

4. Pozycję w związkach zawodowych można scharakteryzować lapidarnie w sposób następujący: to co usłyszeliśmy na Kongresie IG Metall w Monachium odnośnie akcji państw Układu Warszawskiego, jest reprezentatywne dla wszystkich związków zawodowych i nadal obowiązuje.

Niemniej jednak już dziś należy zwrócić uwagę na bardzo charakterystyczny fakt. Chodzi mianowicie o to, że mimo utrzymującej się nadal negatywnej oceny, należy 
uznać, że mamy już za sobą pierwszy szok, czego wyrazem jest pogłębiająca się tendencja wśród branżowych związków zawodowych do uchylenia uchwały DGB $^{25}$ w sprawie przerwania kontaktów z organizacjami zawodowymi pięciu państw Europy wschodniej. Tego rodzaju tendencje wystapiły bardzo wyraźnie w Związku Zawodowym Przemysłu Poligraficznego i Przetwórstwa Papierniczego /IG Druck und Papier/ oraz zarysowują się powoli w Związku Zawodowym Pocztowców /Deutsche Postgewerkschaft/.

Nie należy też wykluczyć, że w najbliższym czasie, pójdzie w te same ślady Związek Zawodowy Pracowników Służby Publicznej, Transportu i Komunikacji /Gew. Öffentliche Dienste, Transport, Verkehr/. Zwłaszcza IG Druck und Papier stoi na stanowisku, że jeśli nie chce się przerywać polityki odprężeniowej, to nie wolno jednocześnie dystansować się od nawiązanych już kontaktów ze związkami państw socjalistycznych.

Niemniej wydaje się być symptomatyczne, że w dołowych organizacjach różnych związków branżowych występuje jakgdyby pewna polaryzacja postaw i to w tym sensie, że nasze argumenty zaczynaja powoli torować sobie drogę do poszczególnych umysłów, co można uznać za moment bardzo pomyślny. Oczywiście jest to proces bardzo powolny i jeszcze bardzo daleki od zadawalającego.

\footnotetext{
${ }^{25}$ Deutscher Gewerkschaftsbund, Niemieckie Zrzeszenie Związków Zawodowych.
} 